\title{
Uji Beberapa Zat Pengatur Tumbuh Terhadap Pertumbuhan Setek Lada Perdu (Piper nigrum L.)
}

\author{
WAHYUDI $^{1}$, MADE DEVIANI DUAJA $^{1}$, ELIS KARTIKA ${ }^{1}$ \\ ${ }^{1}$ Program Studi Agroekoteknologi, Fakultas Pertanian, Universitas Jambi \\ Jl. Lintas Jambi-Muara Bulian Km 15, Mendalo Darat, Kota Jambi, Jambi. 36122 \\ Email: madedevianiduaja@yahoo.com
}

Received 6 April 2018; Received in revised form 23 April 2018;

Accepted 25 May 2018; Available online 26 November 2018

\begin{abstract}
Pepper (Piper nigrum L.) is a commodity of high economic value, but the production is still low. The main reason is the lack of availability for good pepper seedling. Pepper has been commercially propagated by cuttings. To optimize pepper cutting growth could be done through the application of plant growth regulator (PGR). PGR can also be obtained from plant extracts. Some parts of the plant can be used as an exogenous growth regulator hence it contains many hormones that plants need. This experiment was conducted at Teaching and Research Farm, Universitas Jambi to select the best plant extract as an exogenous growth regulator that could induce root and growth of pepper cutting. Five plant extracts, animal urine, and synthetic growth regulator were used as treatment namely: Rootone-F as control, coconut water (Cocos nucifera L.), cow urine, extract of mung bean sprouts (Vigna radiata) + moringa leaf extract (Moringa sp.), young corn (Zea mays) seed extract + moringa leaf extract, young corn seed extract + moringa leaf extract, bamboo shoot extract + banana hump (Musa paradisiaca) extract. The experiment was set in the form of randomized complete design with three replications. Result revealed that synthetic plant growth regulators and plant extracts as exogenous growth regulator have a significant effect on the growth of pepper cuttings. Coconut water gave the best of pepper seedling growth based on the percentage of live seedling, percentage of cutting sprouts, shoot length, root length and shoot dry weight.
\end{abstract}

Keywords: bamboo, cutting, moringa, plant extract, seedling

\section{INTISARI}

Lada (Piper nigrum L.) merupakan komoditas yang bernilai ekonomis tinggi, akan tetapi produktivitasnya masih rendah. Perbanyakan lada dilakukan dengan setek. Keberhasilan setek lada dapat ditingkatkan dengan cara pemberian zat pengatur tumbuh (ZPT). Zat pengatur tanaman dapat juga diperoleh dengan mengekstrak bagian tertentu dari tanaman. Penelitian ini dilaksanakan di Teaching and Research Farm, Universitas Jambi dengan tujuan untuk mendapatkan jenis ZPT yang paling tepat untuk pertumbuhan setek lada perdu. Rancangan percobaan yang digunakan adalah Rancangan Acak Lengkap yang terdiri dari 7 perlakuan yaitu: Rootone-F, air kelapa muda, urin sapi, ekstrak kecambah kacang hijau + ekstrak daun kelor, ekstrak biji jagung muda + ekstrak daun kelor, ekstrak rebung bambu dan ekstrak bonggol pisang. Parameter yang diamati yaitu persentase setek hidup, persentase setek bertunas, persentase setek berakar, panjang tunas, diameter tunas, panjang akar, bobot kering tunas dan bobot kering akar. Hasil penelitian ini menunjukkan bahwa zat pengatur tumbuh sintetis dan zat pengatur tumbuh alami dapat memberikan pengaruh yang nyata terhadap pertumbuhan setek lada perdu. Zat pengatur tumbuh alami dari air kelapa dapat meningkatkan pertumbuhan setek tanaman lada perdu.

Kata Kunci: air kelapa, kacang hijau, kelor, rebung bambu, urin

\section{PENDAHULUAN}

Lada (Piper nigrum L.) merupakan salah satu tanaman rempah-rempah yang penting di Indonesia, akan tetapi produktivitasnya masih sangat rendah. Pada tahun 2017, produksi lada nasional adalah sebesar 82.964 ton, sedangkan sentra produksi lada di Provinsi Jambi di tahun yang sama hanya sebesar 35 ton (Kementerian Pertanian, 2017). Jika dibandingkan dengan produktivitas nasional, produksi lada di Provinsi Jambi masih rendah. Penggunaan varietas unggul dan perbanyakan vegetatif dengan setek merupakan salah satu cara untuk memacu peningkatan produktivitas (Amri et al., 2010; Donzella et al., 2000). Perbanyakan lada dengan setek cabang produksi (setek cabang buah) digunakan untuk menghasilkan bibit lada perdu. Keuntungan menanam lada perdu jika dibandingkan lada panjat yaitu bahan tanaman banyak tersedia, tidak perlu tiang panjat, jumlah tanaman per hektar lebih banyak, pemeliharaan dan panen lebih praktis. Kerapatan tanam lada panjat adalah 1600 tanaman/ha, maka untuk lada perdu 
kerapatannya dapat mencapai 4500 tanaman per hektarnya (Rukmana, 2010; Rukmana, 2003). Perbanyakan vegetatif dengan setek dinilai lebih efisien dan efektif serta adanya kesamaan sifat bibit anakan dengan pohon induknya (Abbasi et al., 2010; Aguzaen, 2009). Kendala yang dihadapi dalam perbanyakan dengan setek yaitu sulitnya pertumbuhan akar, sehingga tingkat keberhasilannya rendah.

Untuk mempercepat pertumbuhan akar dapat dilakukan dengan penambahan aplikasi zat pengatur tumbuh (ZPT) alami dan sintetis. ZPT alami dapat ditemukan di alam dan berasal dari bahan organik seperti air kelapa, urin sapi, keong, dan ekstrak bagian tanaman (rizoma, akar, batang, daun, buah, bunga, kulit, biji) yang mampu mempercepat tumbuhnya akar sekunder dan panjang akar, meningkatkan jumlah akar per stek serta meningkatkan berat kering tanaman (Abdelgadir et al., 2010; Mohamed and Abdel-Gawad, 2005; Ramachandrudu and Thangam, 2007). ZPT alami bersifat ramah lingkungan dan lebih murah. Sedangkan ZPT sintetis merupakan alternatif dari penggunaan ZPT alami, karena daya kerja yang jauh lebih cepat dibandingkan dengan ZPT alami. Akan tetapi memiliki kelemahan tidak ramah lingkungan (Kocaman and Güven, 2016). ZPT sintetis yang paling baik digunakan untuk merangsang pertumbuhan akar setek yaitu Rootone-F. Hal ini sesuai dengan penelitian Sudomo dkk. (2013) yang membuktikan Rootone-F mampu menginduksi panjang akar Manglietia glauca sebesar 34,46\%. Sedangkan Sulistiana (2013) menyimpulkan pemberian Rootone-F 0,2 dan $0,4 \mathrm{~g} / \mathrm{stek}$ memberikan hasil terbaik pada parameter jumlah akar, bobot basah akar dam bobot kering stek daun Sansevieria parva. Pemberian kombinasi ZPT alami dan sintetis juga menunjukkan hasil yang berpengaruh nyata dalam pertumbuhan tunas tanaman teh (Camellia sinensis) (Saefas dkk., 2017).

Penggunaan ZPT dalam merangsang tumbuhnya akar dan tunas pada setek lada perlu memperhatikan keuntungan ekonominya. Salah satu cara yang tepat yaitu menggunakan ekstrak tanaman yang berpotensi sebagai ZPT. Tujuan dari penelitian ini adalah untuk mendapatkan ZPT terbaik dari ekstrak beberapa tanaman terhadap pertumbuhan setek lada perdu.

\section{METODE}

Penelitian ini dilaksanakan di Teaching and Research Farm, Fakultas Pertanian, Universitas Jambi. Rancangan percobaan yang digunakan adalah Rancangan Acak Lengkap (RAL) dengan 1 faktor yaitu pemberian ZPT. Perlakuan terdiri dari 7 taraf dan masingmasing perlakuan dengan 4 ulangan. Adapun taraf perlakuan yang digunakan sebagai berikut:

$\mathrm{d}_{0}=$ Rootone-F $\quad 12,5 \quad \mathrm{~g} / \mathrm{l} \quad(12,5 \quad$ gram Rootone-F + $1000 \mathrm{ml}$ air mineral, bahan setek direndam selama 8 jam)

$\mathrm{d}_{1}=$ Air kelapa muda konsentrasi 25\% (250 $\mathrm{ml}$ air kelapa $+750 \mathrm{ml}$ air mineral, bahan setek direndam selama 8 jam)

$\mathrm{d}_{2}=$ Urin sapi konsentrasi $25 \%$ (250 ml urin sapi $+750 \mathrm{ml}$ air mineral, bahan setek direndam selama 8 jam)

$\mathrm{d}_{3}=$ Ekstrak kecambah kacang hijau + ekstrak daun kelor 25\% (250 ml ekstrak kecambah kacang hijau dan ekstrak daun kelor $+750 \mathrm{ml}$ air mineral, bahan setek direndam selama 8 jam)

$\mathrm{d}_{4}=$ Ekstrak biji jagung muda + ekstrak daun kelor $25 \%$ (250 ml ekstrak biji jagung muda dan ekstrak daun kelor + $750 \mathrm{ml}$ air mineral, bahan setek direndam selama 8 jam)

$\mathrm{d}_{5}=$ Ekstrak rebung bambu $25 \%(250 \mathrm{ml}$ ekstrak rebung bambu $+750 \mathrm{ml}$ air mineral, bahan setek direndam selama 8 jam)

$\mathrm{d}_{6}=$ Ekstrak bonggol pisang $25 \%(250 \mathrm{ml}$ ekstrak bonggol pisang $+750 \mathrm{ml}$ air mineral, bahan setek direndam selama 8 jam)

Parameter yang diamati yaitu persentase setek hidup, persentase setek bertunas, persentase setek berakar, panjang tunas, diameter tunas, panjang akar, bobot kering tunas dan bobot kering akar.

\section{HASIL}

Persentase Setek Hidup. Rata-rata persentase setek hidup pada pemberian 
beberapa jenis zat pengatur tumbuh disajikan pada Tabel 1.

Tabel 1. Rata-rata persentase setek hidup lada perdu pada beberapa jenis zat pengatur tumbuh

\begin{tabular}{cc}
\hline Jenis zat pengatur tumbuh & Persentase setek hidup (\%) \\
Rootone-F & $65,0 \mathrm{ab}$ \\
Air kelapa muda & $75,0 \mathrm{a}$ \\
Urin sapi & $50,0 \mathrm{c}$ \\
Ekstrak kecambah kacang hijau + ekstrak daun kelor & $52,5 \mathrm{bc}$ \\
Ekstrak biji jagung muda + ekstrak daun kelor & $47,5 \mathrm{c}$ \\
Ekstrak rebung bambu & $47,5 \mathrm{c}$ \\
Ekstrak bonggol pisang & $67,5 \mathrm{a}$ \\
\hline
\end{tabular}

Ket: Angka-angka yang diikuti oleh huruf yang berbeda menunjukan berbeda nyata berdasarkan uji Duncan pada taraf $\alpha 5 \%$.

Berdasarkan Tabel 1 terlihat bahwa persentase setek hidup yang tertinggi pada perlakuan pemberian air kelapa muda yang berbeda nyata dengan perlakuan lainnya, kecuali dengan perlakuan ekstrak bonggol pisang dan Rootone-F.
Persentase Setek Bertunas. Rata-rata persentase setek bertunas pada pemberian beberapa jenis zat pengatur tumbuh disajikan pada Tabel 2.

Tabel 2. Rata-rata persentase setek bertunas lada perdu pada beberapa jenis zat pengatur tumbuh

\begin{tabular}{cc}
\hline Jenis zat pengatur tumbuh & Persentase setek bertunas $(\%)$ \\
\hline Rootone-F & $81 \mathrm{a}$ \\
Air kelapa muda & $93 \mathrm{a}$ \\
Urin sapi & $75 \mathrm{a}$ \\
Ekstrak kecambah kacang hijau + ekstrak daun kelor & $77 \mathrm{a}$ \\
Ekstrak biji jagung muda + ekstrak daun kelor & $79 \mathrm{a}$ \\
Ekstrak rebung bambu & $18 \mathrm{~b}$ \\
Ekstrak bonggol pisang & $72 \mathrm{a}$ \\
\hline
\end{tabular}

Ket: Angka-angka yang diikuti oleh huruf yang berbeda menunjukan berbeda nyata berdasarkan uji Duncan pada taraf $\alpha 5 \%$

Berdasarkan Tabel 2, terlihat bahwa persentase setek bertunas yang tertinggi pada perlakuan air kelapa muda yang pengaruhnya berbeda nyata dengan ekstrak bonggol pisang namun tidak berbeda nyata dengan perlakuan lainnya.

Persentase Setek Berakar. Rata-rata persentase setek berakar pada beberapa jenis zat pengatur tumbuh disajikan pada Tabel 3 .

Tabel 3. Rata-rata persentase setek berakar pada beberapa jenis zat pengatur tumbuh

\begin{tabular}{cc}
\hline Jenis zat pengatur tumbuh & Persentase setek berakar (\%) \\
\hline Rootone-F & $80 \mathrm{a}$ \\
Air kelapa muda & $85 \mathrm{a}$ \\
Urin sapi & $55 \mathrm{~d}$ \\
Ekstrak kecambah kacang hijau + ekstrak daun kelor & $65 \mathrm{bc}$ \\
Ekstrak biji jagung muda + ekstrak daun kelor & $70 \mathrm{~b}$ \\
Ekstrak rebung bambu & $50 \mathrm{e}$ \\
Ekstrak bonggol pisang & $60 \mathrm{~cd}$ \\
\hline
\end{tabular}

Ket: Angka-angka yang diikuti oleh huruf yang berbeda menunjukan berbeda nyata berdasarkan uji Duncan pada taraf $\alpha 5 \%$

Berdasarkan Tabel 3, terlihat bahwa persentase setek berakar yang tertinggi pada perlakuan pemberian air kelapa muda yang berbeda nyata dengan perlakuan lainnya, kecuali dengan perlakuan Rootone-F 
Persentase setek berakar terendah pada ekstrak rebung bambu.
Panjang Tunas. Rata-rata panjang tunas pada pemberian beberapa jenis zat pengatur tumbuh disajikan pada Tabel 4.

Tabel 4. Rata-rata panjang tunas pada beberapa jenis zat pengatur tumbuh

\begin{tabular}{cc}
\hline Jenis zat pengatur tumbuh & Panjang tunas (cm) \\
\hline Rootone-F & $2,22 \mathrm{~b}$ \\
Air kelapa muda & $3,47 \mathrm{a}$ \\
Urin sapi & $1,39 \mathrm{~d}$ \\
Ekstrak kecambah kacang hijau + ekstrak daun kelor & $2,37 \mathrm{~b}$ \\
Ekstrak biji jagung muda + ekstrak daun kelor & $1,71 \mathrm{c}$ \\
Ekstrak rebung bambu & $0,08 \mathrm{e}$ \\
Ekstrak bonggol pisang & $2,25 \mathrm{~b}$ \\
\hline
\end{tabular}

Ket: Angka-angka yang diikuti oleh huruf yang berbeda menunjukan berbeda nyata berdasarkan uji Duncan pada taraf $\alpha 5 \%$

Berdasarkan Tabel 4, terlihat bahwa panjang tunas yang tertinggi pada perlakuan air kelapa muda yang pengaruhnya berbeda nyata dengan perlakuan lainnya.
Diameter Tunas. Rata-rata diameter tunas pada pemberian beberapa jenis zat pengatur tumbuh disajikan pada Tabel 5 .

Tabel 5. Rata-rata diameter tunas pada beberapa jenis zat pengatur tumbuh

\begin{tabular}{cc}
\hline Jenis zat pengatur tumbuh & Diameter tunas $(\mathrm{mm})$ \\
\hline Rootone-F & $1,87 \mathrm{ab}$ \\
Air kelapa muda & $2,44 \mathrm{a}$ \\
Urin sapi & $1,27 \mathrm{~b}$ \\
Ekstrak kecambah kacang hijau + ekstrak daun kelor & $1,90 \mathrm{ab}$ \\
Ekstrak biji jagung muda + Ekstrak daun kelor & $1,99 \mathrm{a}$ \\
Ekstrak rebung bambu & $0,11 \mathrm{c}$ \\
Ekstrak bonggol pisang & $1,84 \mathrm{ab}$ \\
\hline
\end{tabular}

Ket: Angka-angka yang diikuti oleh huruf yang berbeda menunjukan berbeda nyata berdasarkan uji Duncan pada taraf $\alpha 5 \%$

Berdasarkan Tabel 5, terlihat bahwa diameter tunas yang tertinggi pada perlakuan air kelapa muda yang pengaruhnya berbeda nyata dengan perlakuan urin sapi dan rebung bambu serta tidak berbeda nyata dengan perlakuan lainnya.

Panjang Akar. Rata-rata panjang akar pada pemberian beberapa jenis zat pengatur tumbuh disajikan pada Tabel 6 .

Tabel 6. Rata-rata panjang akar pada pemberian beberapa jenis zat pengatur tumbuh

\begin{tabular}{cc}
\hline Jenis zat pengatur tumbuh & Panjang akar $(\mathrm{cm})$ \\
\hline Rootone-F & $7,3 \mathrm{~b}$ \\
Air kelapa muda & $10,0 \mathrm{a}$ \\
Urin sapi & $4,9 \mathrm{c}$ \\
Ekstrak kecambah kacang hijau + ekstrak daun kelor & $5,0 \mathrm{c}$ \\
Ekstrak biji jagung muda + ekstrak daun kelor & $5,6 \mathrm{c}$ \\
Ekstrak rebung bambu & $0,3 \mathrm{~d}$ \\
Ekstrak bonggol pisang & $5,6 \mathrm{c}$ \\
\hline
\end{tabular}

Ket: Angka-angka yang diikuti oleh huruf yang berbeda menunjukan berbeda nyata berdasarkan uji Duncan pada taraf $\alpha 5 \%$

Berdasarkan Tabel 6, terlihat bahwa panjang akar yang tertinggi pada perlakuan air kelapa muda yang pengaruhnya berbeda nyata dengan perlakuan lainnya.
Bobot Kering Tunas. Rata-rata bobot kering tunas pada beberapa jenis zat pengatur tumbuh disajikan pada Tabel 7. 
Tabel 7. Rata-rata bobot kering tunas pada beberapa jenis zat pengatur tumbuh

\begin{tabular}{cc}
\hline Jenis zat pengatur tumbuh & Bobot kering tunas $(\mathrm{g})$ \\
\hline Rootone-F & $0,0305 \mathrm{~b}$ \\
Air kelapa muda & $0,0669 \mathrm{a}$ \\
Urin sapi & $0,0182 \mathrm{~d}$ \\
Ekstrak kecambah kacang hijau + ekstrak daun kelor & $0,0285 \mathrm{~b}$ \\
Ekstrak biji jagung muda + ekstrak daun kelor & $0,0279 \mathrm{~b}$ \\
Ekstrak rebung bambu & $0,0013 \mathrm{e}$ \\
Ekstrak bonggol pisang & $0,0244 \mathrm{c}$ \\
\hline
\end{tabular}

Ket: Angka-angka yang diikuti oleh huruf yang berbeda menunjukan berbeda nyata berdasarkan uji Duncan pada taraf $\alpha 5 \%$

Berdasarkan Tabel 7, terlihat bahwa bobot kering tunas tertinggi terdapat pada perlakuan air kelapa muda yang pengaruhnya berbeda nyata dengan perlakuan lainya.
Bobot Kering Akar. Rata-rata bobot kering akar pada pemberian beberapa jenis zat pengatur tumbuh disajikan pada Tabel 8.

Tabel 8. Rata-rata bobot kering akar pada beberapa jenis zat pengatur tumbuh

\begin{tabular}{cc}
\hline Jenis zat pengatur tumbuh & Bobot kering akar $(\mathrm{g})$ \\
\hline Rootone-F & $0,0450 \mathrm{abc}$ \\
Air kelapa muda & $0,0497 \mathrm{ab}$ \\
Urin sapi & $0,0321 \mathrm{c}$ \\
Ekstrak kecambah kacang hijau + ekstrak daun kelor & $0,0375 \mathrm{bc}$ \\
Ekstrak biji jagung muda + ekstrak daun kelor & $0,0379 \mathrm{bc}$ \\
Ekstrak rebung bambu & $0,0019 \mathrm{~d}$ \\
Ekstrak bonggol pisang & $0,0510 \mathrm{a}$ \\
\hline
\end{tabular}

Ket: Angka-angka yang diikuti oleh huruf yang berbeda menunjukan berbeda nyata berdasarkan uji Duncan pada taraf $\alpha 5 \%$

Berdasarkan Tabel 8, terlihat bahwa bobot kering akar tertinggi terdapat pada perlakuan ekstrak bonggol pisang yang pengaruhnya berbeda nyata dengan perlakuan lainnya, kecuali dengan pemberian perlakuan Rootone$\mathrm{F}$ dan air kelapa muda.

\section{PEMBAHASAN}

Hasil penelitian ini menunjukkan bahwa ZPT sintetis dan ekstrak tanaman yang digunakan sebagai ZPT alami menunjukkan pengaruh yang nyata pada persentase setek hidup lada perdu. Dari tabel 1, persentase stek hidup tertinggi pada ekstrak bonggol pisang dan air kelapa muda dan tidak berbeda nyata dengan Rootone-F. Hasil penelitian ini didukung oleh penelitian Kurniati dkk. (2017) bahwa aplikasi bonggol pisang dan air kelapa menghasilkan tinggi bibit tertinggi $13,57 \mathrm{~cm}$, daya kecambah 97,78\% dan jumlah daun terbanyak pada bibit kemiri sunan (Reutealis trisperma) serta penelitian Ulfa et al. (2013) yang menyatakan persentase hidup bibit kentang tertinggi ditemukan pada bibit yang diaplikasikan dengan air kelapa muda dan ekstrak pisang. Ekstrak air kelapa muda mengandung komponen bioaktif dari auksin, sitokinin dan giberelin, sedangkan pisang lebih banyak mengandung auksin (Ohoiulun et al., 2014; Yong et al., 2009). Setek tunas terbanyak ditemukan pada aplikasi ekstrak air kelapa muda dan terendah pada ekstrak rebung bambu (Tabel 2). Auksin pada ekstrak air kelapa muda berperan dalam menstimulasi pertumbuhan sel meristem apikal batang dan pucuk batang, sedangkan rebung bambu yang mengandung giberelin yang lebih berperan pada proses perbanyakan benih lada (Setiawan dan Wahyudi, 2014).

Persentase setek berakar lada perdu tertinggi ditemukan pada ekstrak air kelapa muda (Tabel 3). Begitu pula pada panjang tunas setek lada perdu (Tabel 4), diameter tunas setek lada perdu (Tabel 5), panjang akar (Tabel 6) dan bobot kering tunas akar lada perdu (Tabel 7).

Air kelapa muda mengandung berbagai ZPT alami seperti auksin (2,4-D, IAA, IBA, NAA), sitokinin (kinetin, trans-zeatin, dihydrozeatin, ortho-topolin, BA), giberelin 
(GA), dan asam absisat (ABA) yang berperan dalam berbagai respon fisiologi tanaman pada tahap perkembangan tanaman (Ma et al., 2008; Puspitorini, 2016). ZPT ini dikenal sebagai fitohormon. Proses pembelahan sel, pertumbuhan, diferensiasi sel, pembentukan organ, dormansi dan perkecambahan biji, serta penuaan dan absisi daun maupun organ diatur oleh fitohormon ini (Ma et al., 2008; Yong et al., 2009). Hal ini menjadi penyebab utama, semua parameter tertinggi ditemukan pada aplikasi ekstrak air kelapa muda. Pemberian ekstrak air kelapa 25\% memberikan pengaruh yang tidak jauh berbeda dengan pemberian aplikasi ZPT sintetik Rootone-F 12,5 g/l.

\section{KESIMPULAN}

Zat pengatur tumbuh sintetis dan ekstrak tanaman yang mengandung zat pengatur tumbuh alami mampu meningkatkan pertumbuhan setek lada perdu. ZPT alami dari ekstrak tanaman air kelapa muda dan bonggol pisang mampu meningkatkan pertumbuhan setek tanaman lada perdu terbaik

\section{DAFTAR PUSTAKA}

Abbasi BH, Ahmad N, Fazal H, Mahmood T. 2010. Conventional and modern propagation techniques in Piper nigrum. Journal of Medicinal Plants Research. vol 4(1): $7-12$. https://doi.org/10.5897/JMPR09.025.

Abdelgadir HA, Jäger AK, Johnson SD, Van Staden J. 2010. Influence of plant growth regulators on flowering, fruiting, seed oil content, and oil quality of Jatropha curcas. South African Journal of Botany. vol 76(3): $\quad 440-446$. https://doi.org/10.1016/j.sajb.2010.02.08 8.

Aguzaen H. 2009. Respon Pertumbuhan Bibit Stek Lada (Piper nisrum L.) Terhadap Pemberian Air Kelapa dan Berbagai Jenis CMA. AgronobiS. vol 1(1): 36-47.

Amri E, Lyaruu HVM, Nyomora AS, Kanyeka ZL. 2010. Vegetative propagation of African Blackwood (Dalbergia melanoxylon Guill. \& Perr.): effects of age of donor plant, IBA treatment and cutting position on rooting ability of stem cuttings. New Forest. vol 39(2): 183-194. Donzella G, Spena A, Rotino GL. 2000. Transgenic parthenocarpic eggplants: Superior germplasm for increased winter production. Molecular Breeding. vol 6(1): 79-86. https://doi.org/10.1023/A:100961352909 9.

Kementerian Pertanian. 2017. Statistik Perkebunan Indonesia 2015-2017. Jakarta: Kementerian Pertanian.

Kocaman AY, and Güven B. 2016. In vitro genotoxicity assessment of the synthetic plant growth regulator, 1naphthaleneacetamide. Cytotechnology. vol 68(4): 947-956. https://doi.org/https://doi.org/10.1007/s10 616-015-9847-z.

Kurniati F, Sudartini T, Hidayat D. 2017. Aplikasi Berbagai Bahan ZPT Alami Untuk Meningkatkan Pertumbuhan Bibit Kemiri Sunan (Reutealis trisperma (Blanco) Airy Shaw). Jurnal Agro. vol 4(1): 40-49. https://doi.org/https://doi.org/10.15575/1 307.

Ma Z, Ge L, Lee ASY, Yong JWH, Tan SN, Ong ES. 2008. Simultaneous analysis of different classes of phytohormones in coconut (Cocos nucifera L.) water using high-performance liquid chromatography and liquid chromatography-tandem mass spectrometry after solid-phase extraction. Analytica Chimica Acta. vol 610(2): 274281.

https://doi.org/10.1016/j.aca.2008.01.045.

Mohamed AH, and Abdel-Gawad AE. 2005. Effect of plant growth regulator (mepiquat chloride) on circulating hemocytes and total plasma protein of Biomphalaria alexandrina snails. J. Zool. vol 44: 283303.

Ohoiulun D, Endang Y, Mahmudi M. 2014. The effect of with coconut water content on different concentration of essential Chlorella pyronoidosa Chick. International Journal of Biosciences. vol 5(7): 213-218. https://doi.org/http://dx.doi.org/10.12692/ ijb/5.7.213-218. 
Puspitorini P. 2016. The Sources of Auxin Hormone to Growth of Shoot Pineapple Stem Cutting (Ananas comosus L. Merr.). Journal of Academic Research and Sciences. vol 1(1): 45-52.

Ramachandrudu K, and Thangam M. 2007. Response of Plant Growth Regulators, Coconut Water and Cow Urine on Vegetative Growth, Flowering and Corm Production in Gladiolus. Journal of Ornamental Horticulture. vol 10(1): 3841.

Rukmana D. 2010. Teknik Perbanyakan Setek Lada Melalui Kebun Induk Mini. Buletin Teknik Pertanian. vol 15(2): 63-65.

Rukmana R. 2003. Tanaman Perkebunan: Usaha Tani Lada Perdu. Yogyakarta: Kanisius.

Saefas SA, Rosniawat S, Maxiselly Y. 2017. Pengaruh Konsentrasi Zat Pengatur Tumbuh Alami dan Sintetik Terhadap Pertumbuhan Tanaman Teh (Camellia sinensis (L.) O. Kuntze) Klon GMB 7 Setelah Centering. Kultivasi. vol 16(2): 368-372.

https://doi.org/https://doi.org/10.24198/k1 tv.v16i2.12591.

Setiawan, dan Wahyudi A. 2014. Pengaruh Giberelin Terhadap Pertumbuhan Beberapa Varietas Lada Untuk Penyediaan Benih Secara Cepat. Buletin
Penelitian Tanaman Rempah dan Obat. vol 25(2): 111-118. https://doi.org/http://dx.doi.org/10.21082/ bullittro.v25n2.2014.111-118.

Sudomo A, Rohandi A, Mindawati N. 2013. Penggunaan Zat Pengatur Tumbuh Rootone-F Pada Stek Pucuk Manglid (Manglietia glauca BI). Jurnal Penelitian Hutan Tanaman. vol 10(2): 57-63. https://doi.org/https://doi.org/10.20886/jp ht.2013.10.2.57-63.

Sulistiana S. 2013. Respon Pertumbuhan Stek Daun Lidah Mertua (Sansevieria parva) Pada Pemberian Zat Pengatur Tumbuh Sintetik (Rootone-F) dan Asal Bahan Stek. Jurnal Matematika Sains dan Teknologi. vol 14(2): 107-118.

Ulfa F, Sengin EL, Baharuddin, Syaiful SA, Sennang NR, Rafiuddin, Ifayanti. 2013. Potential of Plant Extracts as Growth Exogenous Regulators of Potato Seeds. International Journal of Agriculture System. vol 1(2): 98-103. https://doi.org/http://dx.doi.org/10.20956/ ijas.v1i2.10.

Yong JWH, Ge L, Ng YF, Tan SN. 2009. The chemical composition and biological properties of coconut (Cocos nucifera L.) water. Molecules. vol 14(12): 5144-5164. https://doi.org/10.3390/molecules141251 44. 